\title{
Preharvest foliar applications of glycine-betaine protects banana fruits from chilling injury during the postharvest stage
}

\author{
Luis C Rodríguez-Zapata ${ }^{*}$, Francisco L Espadas y Gill', Susana Cruz-Martínez ${ }^{1}$, Carlos R Talavera-May', \\ Fernando Contreras-Marin ${ }^{1}$, Gabriela Fuentes ${ }^{1}$, Enrique Sauri-Duch ${ }^{2}$ and Jorge M Santamaría ${ }^{1}$
}

\begin{abstract}
Background: Banana plantations are affected by environmental factors such as chilling injury, which reduces the quality of fruits and causes losses of up to 50\% in the yield of banana and it will be more important in terms of global climate change. Chilling injury of the fruits can also occur during transport and storage at low temperatures, particularly in tropical fruits. In banana, losses of up to $20 \%$ can occur during postharvest handling. Given this situation, it is necessary to explore alternatives that might reduce chilling injury, such as the use of compatible solutes including glycine-betaine (GB).

Results: In the present work, experiments were performed to analyze the possible role of preharvest foliar applications of GB, to prevent the subsequent development of chilling injury of banana fruits during the postharvest storage at low temperatures. After 3 days of the preharvest application of $100 \mathrm{mM} \mathrm{GB}$ over banana leaves $(250 \mathrm{ml} / \mathrm{plant})$, the fruits were harvested and first stored at $10^{\circ} \mathrm{C}$ for $6 \mathrm{~h}$ and then transferred to $23^{\circ} \mathrm{C} \pm 1{ }^{\circ} \mathrm{C}$ until they reached commercial ripening. A second group of plants were not treated with $\mathrm{GB}$ during the preharvest stage, but their fruits were exposed to $10^{\circ} \mathrm{C}$ for $6 \mathrm{~h}$ before transferring them to $23^{\circ} \mathrm{C} \pm 1{ }^{\circ} \mathrm{C}$ until they reached commercial ripening. A control group was untreated with $\mathrm{GB}$ during the preharvest stage, and fruits were not exposed to low temperatures but they were kept at $23^{\circ} \mathrm{C}$ until they reached commercial ripening.

Conclusions: The results showed that the preharvest foliar application of GB (100 mM) to banana plants reduced the biochemical and physiological alterations caused by chilling injury on harvested fruits.
\end{abstract}

Keywords: Glycine-betaine; Chilling injury; Banana; Browning

\section{Background}

One of the factors that limits the establishment of banana plantations at certain latitudes, and has an impact on the development of plants and fruit production, is chilling damage. This loss in fruit production intensifies at the postharvest stage, because losses between $15 \%$ and $25 \%$ of production can occur at that stage [1]. Bananas are sensitive to chilling and suffer physiological damage when exposed to environment temperatures below the critical point $\left(11^{\circ} \mathrm{C}\right)$ regardless of the type of cultivar [2,3]. It is considered that the primary cause of injuries caused by chilling are the changes in the properties of the cell membrane [4] that causes a cascade of secondary reactions,

\footnotetext{
* Correspondence: Icrz@cicy.mx

${ }^{1}$ Unidad de Biotecnología, Centro de Investigación Científica de Yucatán, Mérida 97200, México

Full list of author information is available at the end of the article
}

which include the increase in the production of ethylene, increase in anaerobic respiration, and reduced photosynthesis [4-6]. Chilling-tolerant plants use evasion and tolerance mechanisms such as the synthesis of lowmolecular-weight compounds called compatible solutes $[4,7,8]$. Compatible solutes include sugars such as trehalose and mannitol, amino acids such as proline, and amino acid derivatives such as glycine-betaine (GB) [9]. Plants capable of accumulating these osmolytes are able to survive under conditions of stress by drought, salinity, and chilling. GB is a quaternary ammonium compound that is a very effective compatible solute [10-12] and is found in a wide range of foods [13]. In plants that synthesize GB, which are known as GB accumulators (spinach, maize, and barley), this compatible solute accumulates in leaves in response to drought and salinity, as well as during

\section{Springer}


acclimation to cold $[10,14,15]$. Moreover, GB has been shown in vitro to stabilize membranes of the oxygenevolving photosystem II complex [16,17]. GB also stabilizes the activity of ribulose 1,5-bisphosphate carboxylase/ oxygenase in a transgenic cyanobacterium in vivo [18]. In higher plants, GB is synthesized from choline (Cho) via betaine aldehyde (BA). The first and second steps in the biosynthesis of GB are catalyzed by the enzymes choline monooxygenase $(\mathrm{CMO})$ and betaine aldehyde dehydrogenase (BADH), respectively [10]. There is evidence suggesting that $G B$ plays a role in stress tolerance in some species of plants [19]. However, to date, there are no studies on the effect of GB application on climacteric tropical fruits. It has been reported that the browning (lowtemperature injury symptom) in banana peel is caused by the oxidation of polyphenols caused primarily by polyphenol oxidase (PPO) (Yang et al. [20]). Nguyen et al. [21] report that banana fruits exposed to low temperatures experience an increased activity of both phenylalanine ammonia lyase (PAL) and PPO. In chilling-sensitive plants, oxidative stress is a major component of chilling stress and active oxygen species (AOS) such as hydrogen peroxide, superoxide radicals, and hydroxyl radicals that can react very rapidly with DNA, causing severe damage to cellular proteins and lipids [22]. Plants have mechanisms to tolerate different types of stress such as chilling that also causes cellular dehydration. Commonly, plants synthesize compatible soluble compounds to retain water in the cell or to protect cellular components from chilling-induced dehydration [23]. Exogenous applications of GB have been successful in increasing the tolerance to abiotic stresses in various species including Arabidopsis thaliana [24-27]. Moreover, the overexpression of genes codifying for one of the enzymes involved in GB biosynthesis resulted in increased tolerance to various abiotic stresses including chilling [28-31].

Therefore, in the present study, it was intended to evaluate a possible protective role of the preharvest foliar applications of GB on the subsequent physiological and biochemical disorders caused by postharvest lowtemperature storage of banana fruits (cv Giant Dwarf).

\section{Methods}

\section{Plant material}

This work was conducted in banana Musa acuminata cv 'Giant-Dwarf' plants, grown at the nursery of CICY at Mérida Yucatán, Mexico. The fruits were harvested at the first stage of ripening, according to the Customers Services Department Chiquita Brands, Inc., Cincinnati, OH. [32].

\section{Experimental}

Three different groups of five plants each were formed. In the first group (control), distilled water ( $250 \mathrm{ml} /$ plant) was sprayed over the first two leaves near the inflorescence for three consecutive days prior to harvesting the fruits that were kept at $25^{\circ} \mathrm{C}$ until they reach commercial ripening. A second group of plants (chilled fruits) was also treated with distilled water for three consecutive days; the fruits were then harvested, but they were exposed to $10^{\circ} \mathrm{C}$ for $6 \mathrm{~h}$ before they were kept at $23^{\circ} \mathrm{C}$ until they reached commercial ripening. The third group of plants (GBtreated chilled fruits) was treated with $250 \mathrm{ml}$ per plant of a solution of $100 \mathrm{mM} \mathrm{GB}$, sprayed over the first two leaves near the inflorescence, for three consecutive days. The fruits were then harvested and exposed to $10^{\circ} \mathrm{C}$ for $6 \mathrm{~h}$ before they were kept at $23^{\circ} \mathrm{C}$ until they reached commercial ripening. In all temperature treatments, an incubator (Forma Scientific, Diurnal Growth Chamber, Marietta, Ohio, USA) under dark conditions was used. Samples of five fruits from each treatment were taken every $24 \mathrm{~h}$ for 8 or 9 days, to measure the various biochemical and physiological parameters.

\section{Enzymatic activity of polyphenol oxidase (PPO)}

Five grams (fresh weight $(\mathrm{FW})$ ) of fruit peels from the three different groups were homogenized using a polytron (Poly science model X-520, Niles, Illinois, USA) with $10 \mathrm{ml}$ of $0.1 \mathrm{M}$ sodium phosphate buffer $\mathrm{pH} 7$ (0.1 M phosphate monobasic sodium monohydrate and $0.1 \mathrm{M}$ phosphate dibasic hepta hydrated sodium) with protease inhibitors $\left(5 \mu \mathrm{g} \mathrm{ml}^{-1}\right.$ of aprotinin, $5 \mu \mathrm{g} \mathrm{ml}^{-1}$ leupeptine, and $10 \mathrm{mM}$ of phenyl-methyl sulphonyl fluoride (PMSF)), $10 \mathrm{mM}$ ascorbic acid, and 3\% of polyvinyl-polypirrolidone (PVPP). Subsequently, the homogenate was centrifuged to $13,200 \mathrm{rpm}$ for $30 \mathrm{~min}$ at $4^{\circ} \mathrm{C}$. The specific enzymatic activity of PPO was determined according to Tamayo [33] and Arzápalo [34] and expressed as $\mu \mathrm{mol} \mathrm{min}{ }^{-1} \mathrm{mg}^{-1}$ protein.

\section{Quantification of soluble phenols}

One gram (FW) of fruit peels were crushed in a mortar in the presence of liquid nitrogen until obtaining a fine powder. The macerate was transferred to a test tube and $5 \mathrm{ml}$ of a mixture of chilled ethanol $(1: 1 \mathrm{v} / \mathrm{v})$ was added. The homogenate was agitated for $1 \mathrm{~min}$, and it was placed in ice for $6 \mathrm{~h}$. Subsequently, it was centrifuged to 10,000 rpm (Centrifuge 5415 D Eppendorff) for $10 \mathrm{~min}$ at $4^{\circ} \mathrm{C}$; the supernatant was then separated, and this fraction was extracted for the quantification of soluble phenols. Phenol determination was made by the reaction of Folin-Ciocalteu reagent as described by Singlenton and Rossi [35] with slight modifications [21].

\section{Soluble protein quantifications}

One gram (FW) of fruit peels was macerated in a mortar by adding liquid nitrogen and 1.5\% of PVPP $\left(0.015 \mathrm{~g} \mathrm{ml}^{-1}\right)$ to obtain a fine powder. The macerate was transferred to an Eppendorf tube containing $2 \mathrm{ml}$ of extraction buffer

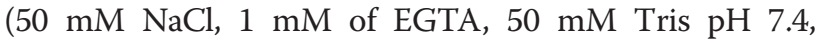
$250 \mathrm{mM}$ sucrose, $10 \%$ glycerol) and protease inhibitors 
(5 $\mu \mathrm{g} \mathrm{ml}^{-1}$ of aprotinin, $5 \mu \mathrm{g} \mathrm{ml}^{-1}$ leupeptine, and $10 \mathrm{mM}$ PMSF). The homogenate was centrifuged to $10,400 \mathrm{rpm}$ at $4^{\circ} \mathrm{C}$ for $30 \mathrm{~min}$. The supernatant was used to determine protein content. Spectrophotometric soluble protein quantification was made as described in Bradford [36].

\section{Measurement of chlorophylls and total carotenoids}

One gram (FW) of fruit peels was crushed in a mortar with liquid nitrogen. Chilled acetone (80\%) was added (10 ml per gram of tissue). The homogenate was vacuum filtered using a funnel with filter paper. The obtained filtrate was left to stand for 30 min under chilling temperatures and darkness, and it was centrifuged for $10 \mathrm{~min}$ at 12,000 rpm. Spectrophotometric (Beckman Coulter DU 650, Beckman Coulter, Inc., Fullerton, CA, USA) measurements of the acetonic extract were made at three different wavelengths $(470,645$, and $663 \mathrm{~nm})$, and chlorophyll and carotenoids concentrations were calculated according to Wellburn [37].

\section{Ethylene and respiration measurement}

Two fruits were placed in a 1-1 glass container hermetically closed and remained in the dark at ambient temperature $\left(23^{\circ} \mathrm{C} \pm 1^{\circ} \mathrm{C}\right)$ for $1 \mathrm{~h}$. Then, $3 \mathrm{ml}$ of the mixture of gases was taken from the glass container and analyzed in a gas chromatograph (Varian Star 3400 cx, Walnut Creek, CA, USA) fitted with two detectors placed in series; the first detector was a thermal conductivity detector (TCD) for $\mathrm{CO}_{2}$, and the second was a flame ionization detector (FID) for ethylene, using hydrogen and air as flame and helium as carrier gas. Standard mixtures of carbon dioxide $\left(\mathrm{CO}_{2}\right) \quad 5,000 \mu \mathrm{mol} \mathrm{mol}{ }^{-1}$, ethylene $50 \mu \mathrm{mol} \mathrm{mol}{ }^{-1}$, and nitrogen were used for calibration. Production of ethylene and respiratory rate assessments were carried out according to McCollum and Mc Donald
[38] and Liu et al. [39] with some modifications from Chillet and Lapeyre de Bebellaire [40].

\section{Cell membrane stability (CMS); electrolyte leakage}

Cell membrane stability (CMS) was measured as electrolyte leakage according to McCollum and McDonald [38] and Prohens et al. [41]. Ten disks (10-cm diameter) of fruit peels from all treatments were placed on $25 \mathrm{ml}$ of mannitol 0.4 M and incubated under agitation for $24 \mathrm{~h}$ at room temperature. Samples were sterilized at $121^{\circ} \mathrm{C}$ to break all tissues and free the electrolytes. Subsequent measurements of electrical conductivity were made with a conductimeter (Orion model 162), using $0.4 \mathrm{M}$ mannitol and de-ionized water solutions as blanks.

\section{Chlorophyll fluorescence}

Fruits were exposed to darkness for 30 min prior to taking the fluorescence measurements. Photochemical efficiency of photosystem II (PSII) measured as the ratio of variable fluorescence over maximal fluorescence $(F \mathrm{v} / F \mathrm{~m})$ was determined with a fluorometer (PEA, Hansatech, Norfolk UK) as reported in Maxwell and Johnson [42].

\section{Statistical analysis}

Each data point is the mean and SD of at least five fruits. The significant difference between treatments were detected by ANOVA with a 95\% confidence level $(P=0.05)$ using StatGraphics Plus 4.1 program. For each parameter measured, ANOVA was performed on the data obtained from the last observation of the experiment.

\section{Results and discussion}

\section{Symptoms of chilling damage}

Figure 1A shows that in control fruits no change occurred in the coloring of the skin (nor on the subepidermal
A) Control $23^{\circ} \mathrm{C}$

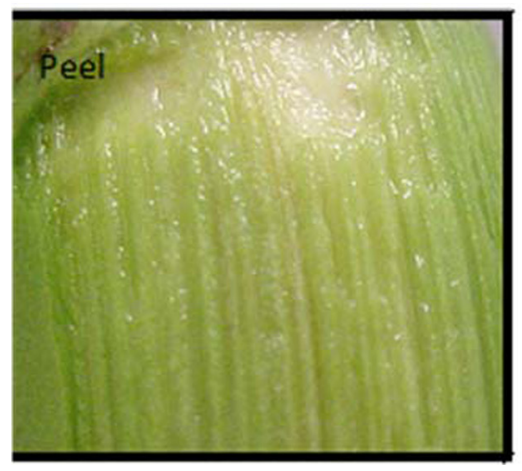

B) $6 \mathrm{~h}$ at $10^{\circ} \mathrm{C}$

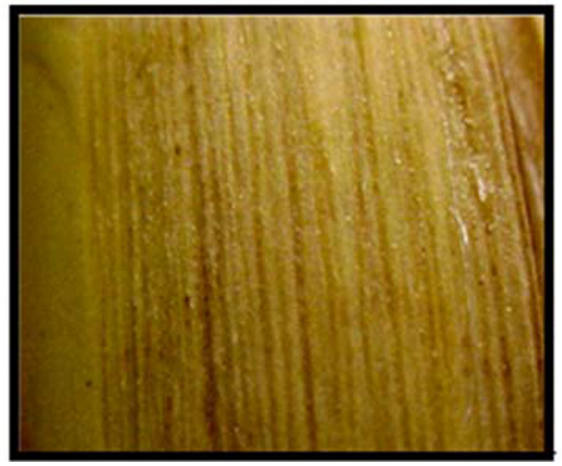

C) $100 \mathrm{mM} \mathrm{G} \mathrm{B} \mathrm{+}$ $6 \mathrm{~h}$ at $10^{\circ} \mathrm{C}$

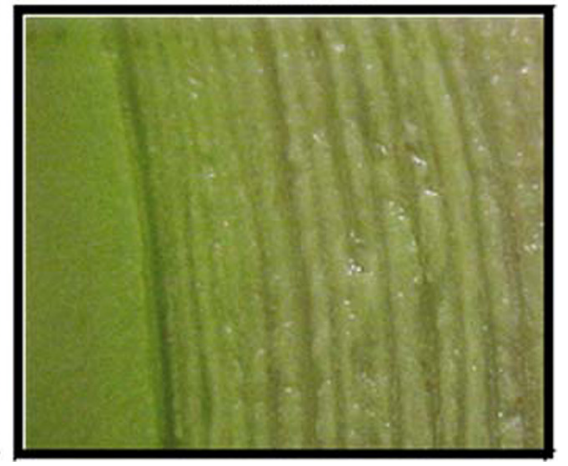

Figure 1 Sub-epidermal tissue from fruits from the 3 treatments. Photographs taken after 8 days of being harvested. The sub-epidermal tissue of banana fruits from the three different treatments: $\mathbf{A}$ ) control fruits from plants treated with distilled water during the preharvest stage and kept at $23^{\circ} \mathrm{C}, \mathbf{B}$ ) fruits from plants treated with distilled water during the preharvest stage but exposed to $10^{\circ} \mathrm{C}$ for $6 \mathrm{~h}$ and then kept at $23^{\circ} \mathrm{C}$, and C) fruits from plants treated during the preharvest stage with $100 \mathrm{mM} \mathrm{GB}$ and exposed to $10^{\circ} \mathrm{C}$ for $6 \mathrm{~h}$ and then kept at $23^{\circ} \mathrm{C}$. 
tissue) within 8 days of being stored at $23^{\circ} \mathrm{C}$. When fruits were exposed to $10^{\circ} \mathrm{C}$ for $6 \mathrm{~h}$ (Figure $1 \mathrm{~B}$ ), they showed obvious signs of chilling damage (browning of the subepidermal tissues). However, when GB was applied during the preharvest stage, the postharvest chilling damage effects (browning) on the fruit was prevented (Figure 1C). These results suggest that banana (cv Giant Dwarf) suffers damage when exposed to chilling $\left(10^{\circ} \mathrm{C}\right)$ even for a short exposure of $6 \mathrm{~h}$, showing uneven ripening and epidermal browning acceleration; similar results were obtained by Morrelli et al. [43], who worked with five different varieties of banana exposed to temperatures of $5^{\circ} \mathrm{C}, 7^{\circ} \mathrm{C}$, and $10^{\circ} \mathrm{C}$, but for as long as 7 days.

Our results also suggest that exogenous GB (when applied to leaves prior to harvesting the fruits) may have been translocated to fruits and had prevented chillinginduced subepidemal browning of fruits. No data on endogenous content of GB are available in our experiment; however, in tomato plants, it was shown that GB was translocated to meristematic tissues including flowers and fruits of tomato when applied exogenously to the leaves and that resulted in increased tolerance to chilling [44].

\section{Total phenols and activity of PPO}

In control fruits, the concentration of total phenols increased four times as the process of ripening progressed (Figure 2A). However, when fruits were exposed for $6 \mathrm{~h}$ to temperatures of $10^{\circ} \mathrm{C}$, the contents of phenols only increased two times irrespective of whether they were treated or not with GB during the preharvest stage.

In terms of PPO-specific activity in control fruits, the PPO-specific activity remained almost constant after 8 days of being harvested (Figure 2B). In chilled fruits, the activity of PPO showed a large peak at Day 3 to later return to basal levels by Day 4 and remained low at Day 8 of being harvested (Figure 2B).

On the contrary, for chilled fruits from plants treated with GB during the preharvest stage, although they also showed an increased PPO activity in response to chilling, this was very much attenuated (i.e., 2,500 $\mu \mathrm{mol} \mathrm{min}{ }^{-1} \mathrm{mg}^{-1}$ protein in GB-treated chilled fruits vs. 6,000 $\mu \mathrm{mol}$ $\min ^{-1} \mathrm{mg}^{-1}$ protein in non-GB-treated chilled fruits).

Our results are in line with findings of other authors in apples and bananas. In apple, some cultivars showed a positive correlation between the degree of browning and enzyme activity. In some cultivars (Classic Delicious, RI Greening, McIntosh, and Cortland), PPO activity was directly related to degree of browning while in others (Empire, Rome, and Golden Delicious), the degree of browning was related more to the final phenolic concentration. High-performance liquid chromatography analysis of the phenolics in apple showed that the types of phenolic compounds in all cultivars were similar and that no one particular compound could account for the

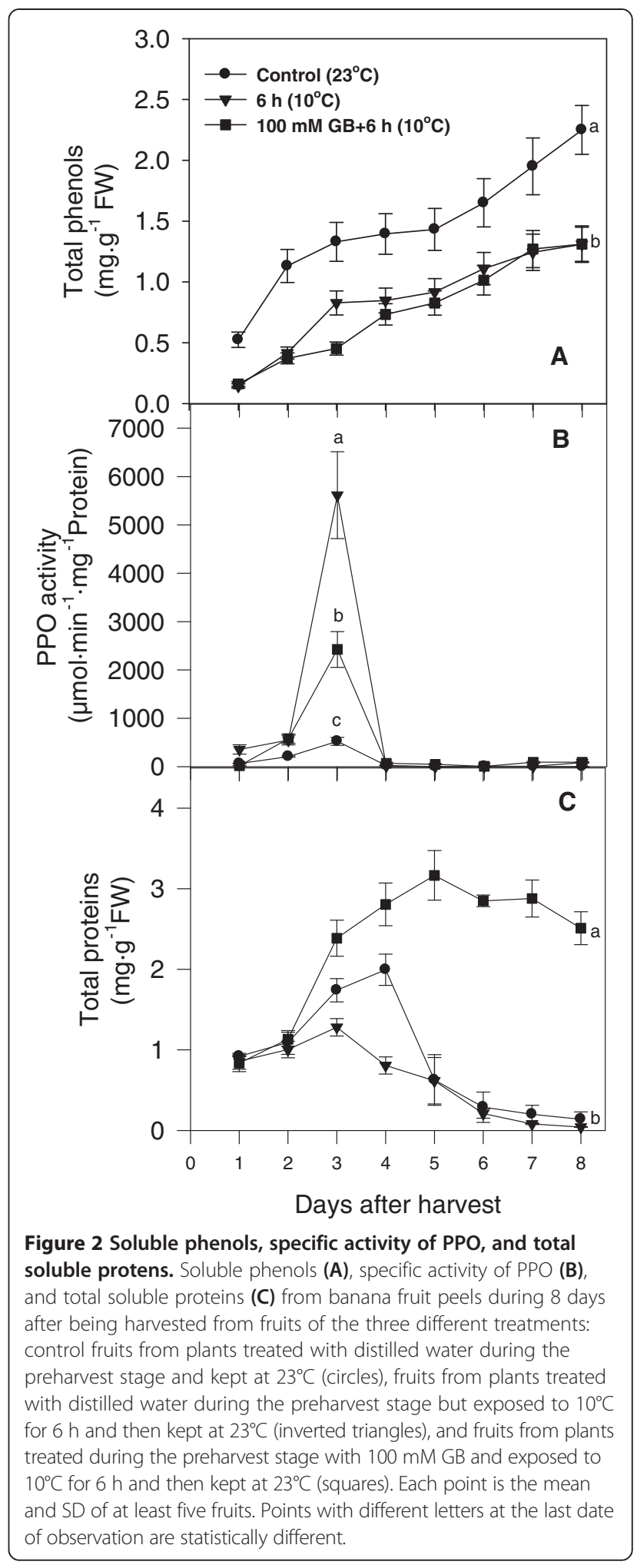

differences observed in browning [45]. They concluded that the increase of the phenolic compounds and the activity of enzymes could be the factor that causes the increase in the degree of browning of fruits when exposed 
to low temperatures [45]; although, this was not the case in all varieties tested.

In banana, on the other hand, Nguyen et al. [21] noted that the development of chilling damage, which causes the fruit skin browning, was due to increased activities of the enzymes PAL and PPO. They found that the banana varieties Kluai Khai and Kluai Hom Tom, exposed to temperatures of $6^{\circ} \mathrm{C}$ and $10^{\circ} \mathrm{C}$, had increased activity of PPO and a greater browning in the fruits. In contrast, Nguyen et al. [46] found that, in another variety of banana, PPO activity did not correlate with phenol content but that it was more related to PAL.

\section{Protein content}

In control fruits, protein content increased in the first 4 days after removal from the plant but declined afterwards being almost 0,8 days after being harvested (Figure 2C). The decline in protein content was not associated to the climacteric peak as it occurred at Day 9 in those fruits (see Figure 3). Chilling caused a reduction in the protein content found in fruits 3 and 4 days after being harvested, when compared to control fruits, followed by a similar decline from Days 5 to 8 after harvest. In contrast, the protein content of chilled fruits from plants preharvestly treated with GB not only prevented the protein degradation associated with the exposure to low temperatures but also perhaps increased the rate of protein synthesis or prevented the ripening-related protein degradation, as protein content in those fruits increased about three times (from 1 to $3 \mathrm{mg}$ of protein $\mathrm{g}^{-1} \mathrm{FW}$ ) at Day 5 but remained high 8 days after being harvested. These results strongly point towards a protecting effect of GB on the rate of proteolysis caused by both the ripening process in control fruits and the chilling-induced proteolysis observed in chilled fruits. GB perhaps promoted the synthesis of new proteins related to the protection of the membrane or reduced the rate of protein degradation or both. There are few reports in banana documenting the changes in the pattern of proteins associated with fruit ripening, but certainly, the observed variation in the protein concentration should be related to the synthesis and hydrolysis of proteins involved in the ripening process. Brady and O'Connell [47] reported that much of the increase in early climacteric-phase protein synthesis is the result of an increase in the turnover of preexisting proteins. On the other hand, Hubbard et al. [48] mentioned that during the climacteric phase of banana fruits there is an increased synthesis of sucrose phosphate synthase (SPS).

\section{Pigments content Total chlorophylls}

In control fruits, total chlorophyll content of peels was reduced from 55 to $20 \mu \mathrm{g} \mathrm{g}^{-1} \mathrm{FW}$, only 1 day after being harvested, and decreases further from 20 to $0 \mu \mathrm{g} \mathrm{g}^{-1} \mathrm{FW}$

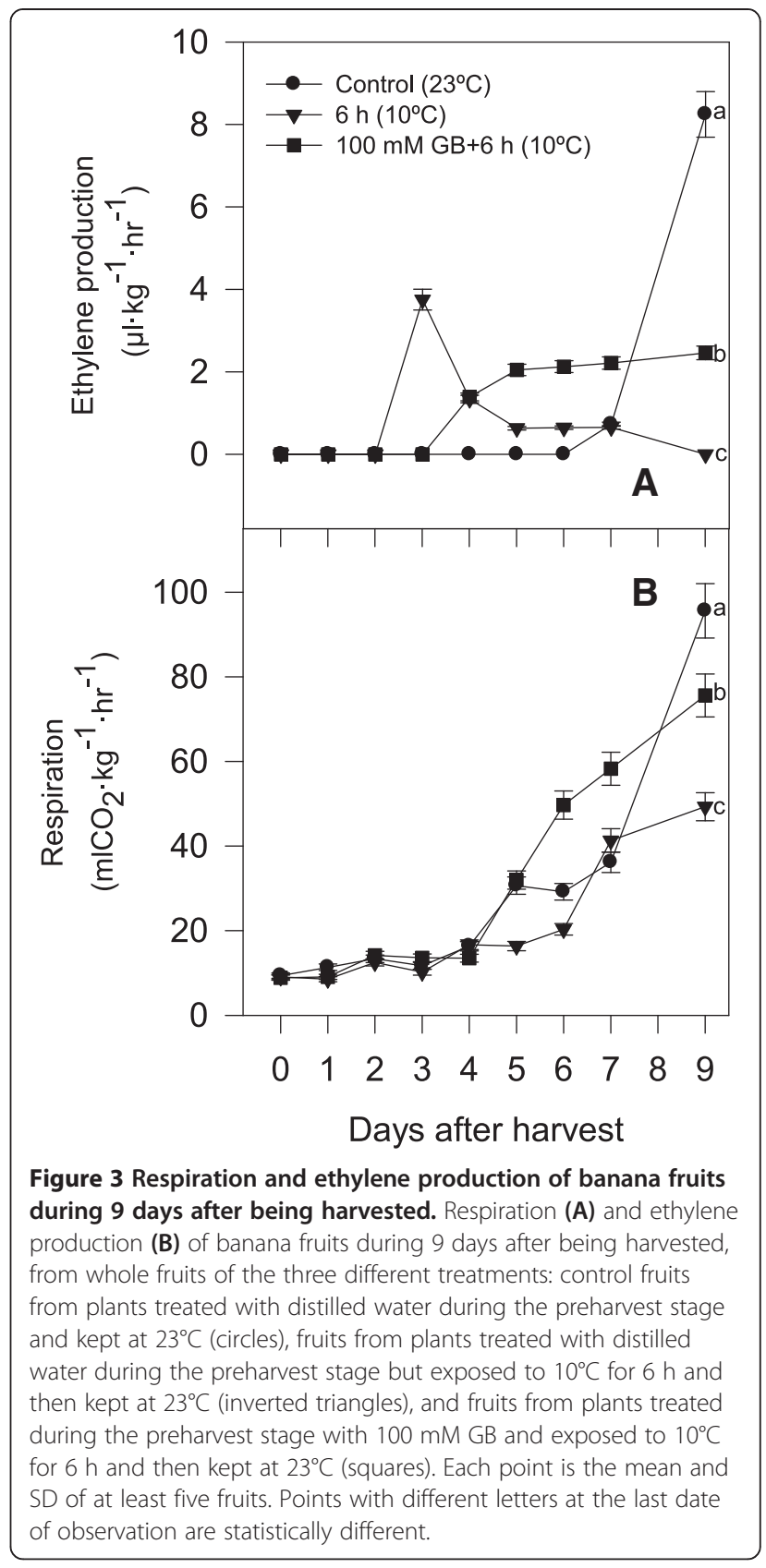

in the following 7 days (Figure 4A). In chilled fruits, the exposure to temperatures of $10^{\circ} \mathrm{C}$ for $6 \mathrm{~h}$ caused a reduction in the rate of chlorophyll degradation during the first 5 days after being harvested; however, it falls at Day 6 to values close to those of the control fruits. In contrast, in chilled fruits from plants treated with GB, the chlorophyll degradation rate was the lowest of the three treatments, remaining at values of $30 \mu \mathrm{g} \mathrm{g}{ }^{-1} \mathrm{FW}$ from Days 5 to 8 after being harvested (Figure 4A). A protective effect of GB on chlorophyll degradation has been reported previously. Blackbourn et al. [49] reported that GB can be 


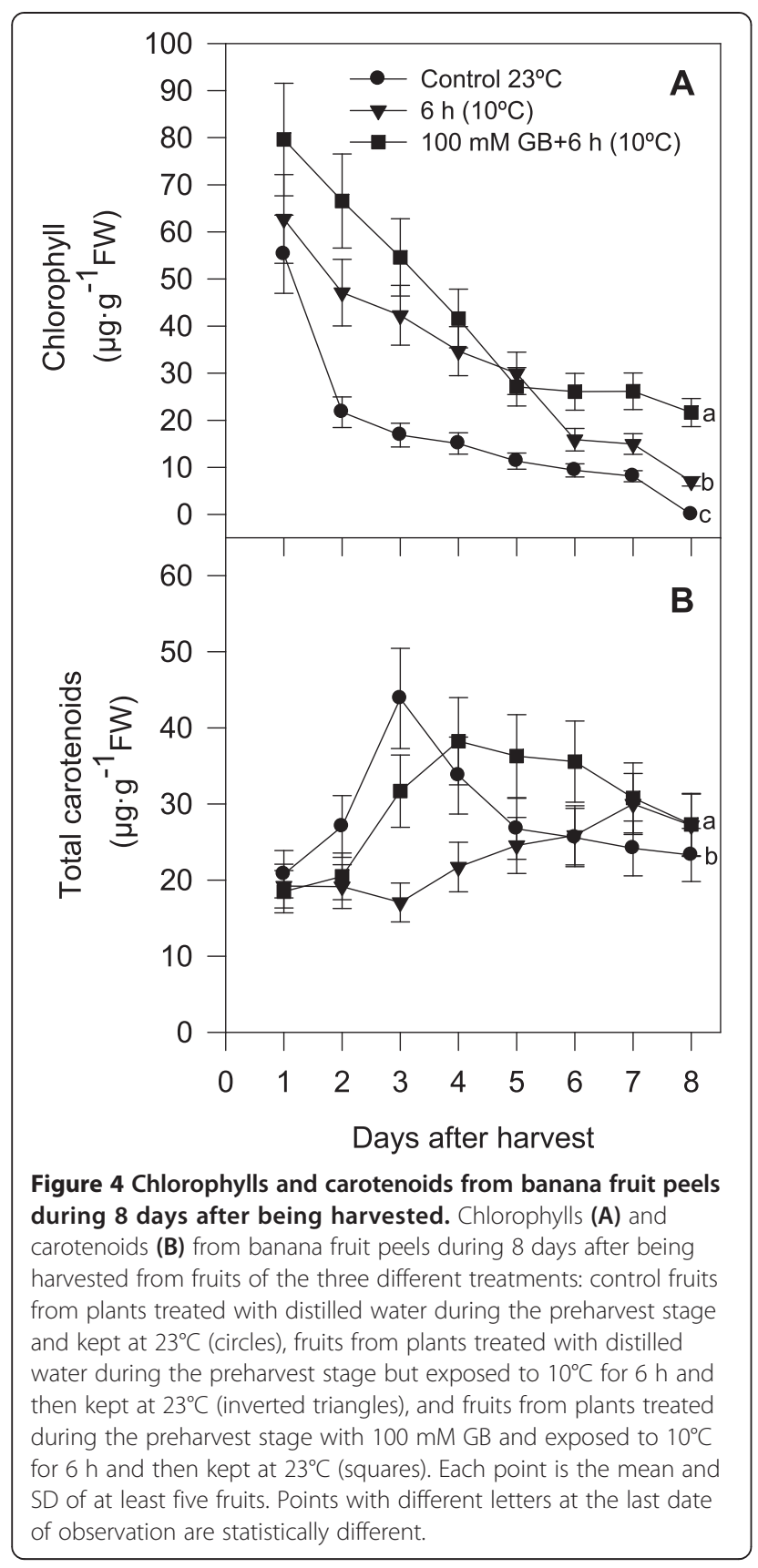

found in chloroplasts and prevents membrane damage caused by peroxidation associated to ROS.

\section{Total carotenoids}

In control fruits, the carotenoid content of peels increased from 20 to $45 \mu \mathrm{g} \mathrm{g}^{-1} \mathrm{FW}$ during the first 3 days but declined later reaching again values of $20 \mu \mathrm{g} \mathrm{g}^{-1} \mathrm{FW}, 8$ days after being harvested. In chilled fruits, exposure to temperatures of $10^{\circ} \mathrm{C}$ for $6 \mathrm{~h}$ caused no damage on the carotenoid content during the first 3 days after being harvested. However, it increased from Days 5 to 8 to values close to
$30 \mu \mathrm{g} \mathrm{g}^{-1} \mathrm{FW}$. In contrast, in chilled fruits from plants treated with GB, during the first 4 days, the carotenoid content increased to values close to those of control fruits, remaining at values around $40 \mu \mathrm{g} \mathrm{g}^{-1} \mathrm{FW}, 6$ days after being harvested and only decreased to values of $30 \mu \mathrm{g} \mathrm{g}^{-1}$ FW at Day 8 (Figure 4B).

\section{Production of ethylene and respiration}

In control fruits, no ethylene was detected during the first 6 days after being harvested; ethylene increased slightly at Day 7 after harvest but showed a significant increase (eightfold) 8 days after being harvested. In chilled fruits, the exposure to temperatures of $10^{\circ} \mathrm{C}$ for $6 \mathrm{~h}$ caused an ethylene peak reaching values of $4 \mu \mathrm{C}_{2} \mathrm{H}_{4} \mathrm{Kg}^{-1} \mathrm{hr}^{-1}$ as early as Day 3 after being harvested, falling again at Day 4 reaching values near $0 \mu \mathrm{C}_{2} \mathrm{H}_{4} \mathrm{Kg}^{-1} \mathrm{hr}^{-1}$ at Day 9 after being harvested.

In contrast, in chilled fruits from plants treated with GB, ethylene also increased by Days 4 and 5 but remained as high as $2 \mu \mathrm{l} \mathrm{C}{ }_{2} \mathrm{H}_{4} \mathrm{Kg}^{-1} \mathrm{hr}^{-1}$ even after 9 days of being harvested (Figure 3A). This result indicates that the chilling caused a premature ethylene peak that resulted in an uneven ripening of the fruit. The preharvest application of GB mitigated this effect, and fruits, despite being subjected to chilling, did not show the premature ethylene peak observed in non-GB-treated chilled fruits. However, chilled fruits from GB-treated plants showed intermediate values of ethylene content between the non-chilled controls and those of the non-GB-treated chilled fruits.

In the case of respiration, in control fruits, low- $\mathrm{CO}_{2}$ rates $\left(10 \mathrm{ml} \mathrm{CO}_{2} \mathrm{Kg}^{-1} \mathrm{hr}^{-1}\right)$ were detected during the first 4 days after being harvested; they increased slightly during Days 5 to 7 , and by Day 9, they showed a significant rise to values near $100 \mathrm{ml} \mathrm{CO}_{2} \mathrm{Kg}^{-1} \mathrm{hr}^{-1}$. Chilled fruits (exposed to temperatures of $10^{\circ} \mathrm{C}$ for $6 \mathrm{~h}$ ) again showed low $\mathrm{CO}_{2}$ during the first 4 days; they did not show an early $\mathrm{CO}_{2}$ peak as the control fruits did. Respiration rates in chilled fruits only increased to values of $30 \mathrm{ml} \mathrm{CO}_{2} \mathrm{Kg}^{-1}$ $\mathrm{hr}^{-1}$ at Day 7 and to values of $50 \mathrm{ml} \mathrm{CO} \mathrm{Kg}^{-1} \mathrm{hr}^{-1}$ by Day 9. In contrast, in chilled fruits from plants treated with $\mathrm{GB}, \mathrm{CO}_{2}$ also remained low during the first 4 days, but from Day 5 onwards, it showed a continuous increase reaching values of $70 \mathrm{ml} \mathrm{CO} \mathrm{Kg}^{-1} \mathrm{hr}^{-1}$ by Day 9 after being harvested (Figure 3B). Those values were again intermediate between the high values observed in control plants and the low values observed in non-GB-treated chilled fruits. There were statistically significant differences between treatments at Day 9. GB perhaps protected proteins involved in the respiration process from chilling injury.

Under conditions of chilling stress, the rate of ethylene and $\mathrm{CO}_{2}$ production usually increases [50-52]. Our results show that in fruit exposed to chilling, respiration declined $48 \%$ with respect to control. While the 
production of ethylene showed a premature peak causing early and uneven ripening of the fruit. These disturbances in the metabolism of the fruit agree with previous reports $[4,53]$. According to Jiang et al. [54], in fruits stored at low temperatures, chilling injuries are due to the reduction in the ability to respond to the ethylene signal, and it has an impact on an abnormal maturation of the fruit. Banana fruit exposed to chilling are perhaps less sensitive to ethylene causing abnormal maturation. Climacteric fruit ripening is a process which is coordinated by the presence of ethylene perception by receptors.

\section{Cell membrane stability}

Exposure of banana fruits to chilling temperatures resulted in changes in the CMS measured as electrolyte leakage. Chilled fruits had electrolyte leakage values of $51 \%$ compared to values of $38 \%$ found in control fruits 10 days after being harvested. Chilling did not affect fruits that were previously treated with $\mathrm{GB}$, as they showed a lower electrolyte leakage $(29.45 \%)$ value that was even lower than that observed in control fruits (Figure 5A). This suggests that GB was protecting the integrity of the membrane perhaps by GB taking action as an osmoregulator that allowed membrane stabilization.

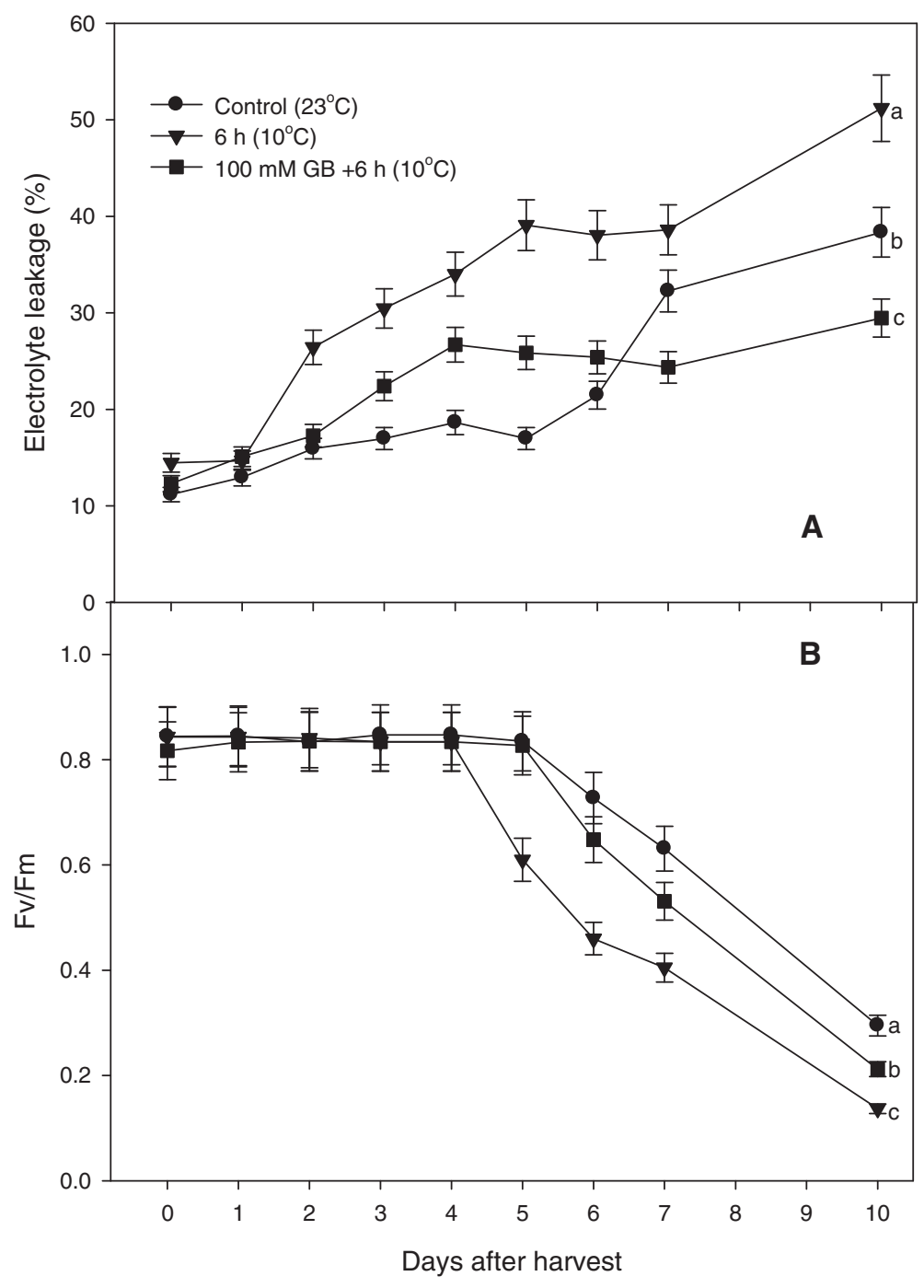

Figure 5 Electrolyte leakage and efficiency of photosystem II from banana fruit peels. Electrolyte leakage (A) and efficiency of photosystem II (B) from banana fruit peels during 10 days after being harvested from fruits of the three different treatments: control fruits from plants treated with distilled water during the preharvest stage and kept at $23^{\circ} \mathrm{C}$ (circles), fruits from plants treated with distilled water during the preharvest stage but exposed to $10^{\circ} \mathrm{C}$ for $6 \mathrm{~h}$ and then kept at $23^{\circ} \mathrm{C}$ (inverted triangles), and fruits from plants treated during the preharvest stage with $100 \mathrm{mM}$ GB and exposed to $10^{\circ} \mathrm{C}$ for $6 \mathrm{~h}$ and then kept at $23^{\circ} \mathrm{C}$ (squares). Each point is the mean and SD of at least five fruits. Points with different letters at the last date of observation are statistically different. 
Other authors also found that the exogenous application of GB allowed chilled tomato plants to maintain lower electrolyte leakage than controls [55]. More recently, $\mathrm{Hu}$ et al. [56] also found that exogenous GB reduced electrolyte leakage in ryegrass and contributed to ameliorate the adverse effects of salt stress.

\section{Activity of photosystem II (Fv/Fm)}

During the first 4 days after harvest, fruits from all three treatments showed no damage to the efficiency of PSII as measured by the ratio-variable chlorophyll fluorescence to maximal fluorescence $(F \mathrm{v} / F \mathrm{~m}) . F \mathrm{v} / F \mathrm{~m}$ values remained above 0.8 that indicate no damage to the efficiency of PSII by Day 4. In fruits exposed to chilling temperatures $\left(10^{\circ} \mathrm{C}\right.$ for $\left.6 \mathrm{~h}\right), \mathrm{Fv} / \mathrm{Fm}$ did fall abruptly by Day 5 reaching values as low as 0.14 by Day 10 of being harvested (Figure 5B). Preharvest application of GB lowered the decline of $F \mathrm{v} / F \mathrm{~m}$ in chilled fruits, as by Day 5 , $F \mathrm{v} / F \mathrm{~m}$ remained as high as in control fruits. By Day 6 , $F \mathrm{v} / F \mathrm{~m}$ began to fall, but this group always showed intermediate $F \mathrm{v} / F \mathrm{~m}$ values between chilled and control groups from Day 6 to Day 10 after being harvested. This might indicate that the application of GB reduced the damage to membranes caused by chilling, perhaps by showing a protective effect on the structure and function of the PSII complex. Previous reports exist of GB's ability to protect the photosynthetic oxygen-evolving complex $[16,17]$.

Although it is argued that a decreased $F \mathrm{v} / F \mathrm{~m}$ in fruits is more associated to the process of fruit senescence [57], resulting from chlorophyll degradation during ripening $[58,59]$, in banana fruits, it has been argued that $\mathrm{Fv} / F \mathrm{~m}$ declines when chlorophyll content decreases as reported by Sanxter et al. [60] or by membrane degradation during ripening as suggested by Marangoni et al. [61]. $F \mathrm{v} / F \mathrm{~m}$ has been mentioned as a good indicator for membrane damage caused by chilling [62,63], and other authors also found that the exogenous application of GB allowed chilled tomato plants to maintain higher $F \mathrm{~V} / F \mathrm{~m}$ values than non-GB-treated chilled fruits [55].

In conclusion, exposure of banana fruits to chilling stress caused fruit browning, an increase in the activity of the PPO when compared to control fruits and consequently a reduction in the concentration of phenols. Thus, the browning of the chilled fruits was not related to the content of phenols. Chilling also caused uneven ripening, an increased degradation of proteins, a reduction in the carotenoid content, and an increase in the content of chlorophylls, membrane damage (increased electrolyte leakage), and reduced efficiency of photosystem II (as shown by low $F \mathrm{v} / F \mathrm{~m}$ values). Chilled fruits also showed an acceleration of ethylene production and a reduction in fruit respiration.
On the contrary, the preharvest foliar application of GB $(100 \mathrm{mM})$ to banana plants reduced the biochemical and physiological alterations caused by chilling injury on their harvested fruits. When fruits from GB-treated plants were exposed to $10^{\circ} \mathrm{C}$ for $6 \mathrm{~h}$, the sub-epidermal browning was attenuated and the accumulation of total phenols was delayed. Similarly, the electron efficiency of photosystem II $(F \mathrm{v} / F \mathrm{~m})$ as well as the CMS remained higher (24\% and $27 \%$, respectively) than in chilled fruits from non-GB-treated plants. It might be possible that the reduction of chilled-induced fruit browning by $G B$ could be associated to a protection of the membrane integrity and protection of photosystem II. GB also seemed to protect proteins from chilling damage, as GB-treated fruits not only did not decrease protein content but even had increased protein content than both the chilled fruits or even the control fruits. GB also increased respiration and prevented the accelerated ripening associated with a premature appearance of an ethylene peak in non-GB-treated chilled fruits. However, it did not have effect on the chilling-related changes on the concentration of phenols or chlorophyll content, but it promoted the synthesis of carotenoids.

Further research is needed to elucidate the cellular and molecular mechanisms that may explain how the preharvest foliar application of GB induced a subsequent protection of fruits to chilling injury. The protection was related to processes of membrane stabilization, electrolyte leakage prevention, and protection to photosystem II, maintaining the photosynthetic efficiency of this protein complex.

In other species such as tomato, it has been suggested that, in addition to protecting macromolecules and membranes directly, GB may enhance chilling tolerance by inducing $\mathrm{H}_{2} \mathrm{O}_{2}$-mediated antioxidant mechanisms, e.g., enhanced catalase expression and catalase activity [55]. These results suggest that GB not only can protect temperate plants from chilling injury including $A$. thaliana (see review by Ashraf and Foolad [27]), but also has a protective effect in tropical plants such as banana. The results of the present work suggest that foliar application of GB might be used in banana plantations to reduce the fruit damage caused by their postharvest storage at low temperature. Our results also might serve as the basis to further evaluate whether the foliar application of GB could also reduce the damage caused by frost-associated chilling injury on banana fruits in the field.

Finally, this study also might give support to the possibility to improve chilling tolerance in this monocot tropical fruit by engineering its capacity to over accumulate GB, in a similar way as it has been achieved in maize [64], rice [28,31], and more recently in sweet potato [65]. 


\section{Competing interests}

The authors declare that they have no competing interests.

\section{Author's contribution}

Luis Carlos Rodríguez-Zapata provided financial support of the experiments from a research grant. Francisco Espadas y Gil assisted in the conduction of field experiments. Susana Cruz Martínez conducted field experiments and most of lab determinations. Carlos Talavera May and Fernando ContrerasMarin assisted in the conduction of field experiments. Gabriela Fuentes contributed to the experimental design and in the manuscript writing. Enrique Sauri-Duch offered expert advice during the conduction of the enzymatic activity assays. Jorge M. Santamaría provided general conception and coordination of the experiments, interpretation of results and manuscript writing. All authors read and approved the final manuscript.

\section{Author details}

'Unidad de Biotecnología, Centro de Investigación Científica de Yucatán, Mérida 97200, México. ${ }^{2}$ Instituto Tecnológico de Mérida, Mérida 97200, México.

\section{Received: 18 April 2014 Accepted: 12 January 2015} Published online: 29 March 2015

\section{References}

1. Pólit C., P. (2005). http://www.sica.gob.ec/agronegocios/sistema\%20valor/ postcosecha_hortifuticolas.htm. (Accessed: October 2, 2005).

2. Salunkhe DK, Desai BB (1984) Postharvest biotechnology of fruits. Lib Congress Florida, United States 1:43-58

3. Jones DR (2000) Ed. Diseases of banana, abaca and emset. Cab Publishing. 560pp. ISBN 0-85199-355-9

4. Levitt J (1980) Responses of plants to environmental stresses. I Chilling, partly and high temperature stresses, vol 1, Secondth edn. Academic, New York, p 497

5. Fitter AH, Hay RKM (1987) Environmental physiology of plants, Secondth edn. Academic Press, San Diego California, pp 197-221

6. Taiz L, Zeiger E (2010) Plant physiology, 5th edn. Sinauer Associates, Inc, USA, pp 755-782

7. Hällgren J, Orquist G (1990) Adaptations to low temperatures. In: Stress responses in plants: adaptation and acclimation mechanism. Wiley-Liss, Inc, Umeå, Sweden, pp 265-293

8. Iba K (2002) Acclimative response to temperature stress in higher plants: approaches of gene engineering for temperature tolerance. Annu Rev Plant Physiol Plant Mol Biol 53:225-245

9. Sakamoto A, Murata N (2000) Genetic engineering of glycinebetaine synthesis in plants: current status and implications for enhancement of stress tolerance. J Exp Bot 51(342):81-88

10. Rhodes D, Hanson AD (1993) Quaternary ammonium and tertiary sulfonium compounds in higher plants. Annu Rev Plant Physiol Plant Mol Biol 44:357-384

11. Rathinasabapathi B (2000) Metabolic engineering for stress tolerance: installing osmoprotectant synthesis pathways. Ann Bot 86:709-716

12. Chen TH, Murata N (2002) Enhancement of tolerance of abiotic stress by metabolic engineering of betaines and other compatible solutes. Curr Opin Plant Biol 5:250-257

13. de Zwart FJ, Slow S, Payne RJ, Lever M, George PM, Gerrard JA, Chambers ST (2003) Glycine betaine and glycine betaine analogues in common foods. Food Chem 83:197-204

14. McCue KF, Hanson AD (1990) Drought and salt tolerance: towards understanding and application. Trends Biotechnol 8:358-362

15. Kishitani S, Watanabe K, Yasuda S, Arakawa K, Takabe T (1994) Accumulation of glycinebetaine during cold acclimation and freezing tolerance in leaves of winter and spring barley plants. Plant Cell Environ 17:89-95

16. Murata N, Mohanty PS, Hayashi H, Papageorgiou GC (1992) Glycinebetaine stabilizes the association of extrinsic proteins with the photosynthetic oxygen-evolving complex. FEBS Lett 296:187-189

17. Papageorgiou GC, Murata N. 1995. The unusually strong stabilizing effects of glycine betaine on the structure and function of the oxygen-evolving photosystem II complex. Photosynthesis Res 44:243-252

18. Nomura M, Hibino T, Takabe T, Sugiura T, Yokota A, Miyake H, Takabe T (1998) Transgenically produced glycinebetaine protects ribulose 1,5-bisphosphate carboxylase/oxygenase from inactivation in Synechococcus sp. PCC7942 under salt stress. Plant and Cell Physiol 39:425-432

19. Giri J (2011) Glycinebetaine and abiotic stress tolerance in plants. Plant Signal Behav 6(11):1746-1751

20. Yang C, Nong L, Lu J-L, Lu L, Xu J-S, Han Y-Z, Li Y-J, Fujita S (2004) Banana polyphenol oxidase: ocurrence and change of polyphenol oxidase activity in some banana cultivars during development. Food Sci Tech RES 10(1):75-78

21. Nguyen TBT, Ketsa S, Van Doorn WG (2003) Relationship between browning and the activities of polyphenol oxidase and phenylalanine ammonia lyase in banana peel, during low temperature storage. Postharvest Life Technol 30:187-193

22. Van Breusegem F, Slooten L, Stassart JM, Moens T, Botterman J, Van Montagu M, Inze D (1999) Overproduction of Arabidopsis thaliana FeSOD confers oxidative stress tolerance to transgenic maize. Plant Cell Physiol 40:515-523

23. Robinson SP, Jones GP (1986) Accumulation of glycinebetaine in chloroplast provides osmotic adjustment during salt stress. Aust J Plant Physiol 13:659-668

24. Like VL, Wilen RW, Fu P (1996) Low-temperature stress tolerance: the role of abscisic acid, sugars and heat stable proteins. Hort Sci Vol 31(1):39-46

25. Chang MY, Chen SL, Lee CF, Chen YM (2000) Chilling acclimation and root protection from chilling injury in chilling-sensitive temperature mungbean (Vigna radiata $\mathrm{L}$ ) seedling. Bot. B. Academic Sw 42:53-59

26. Sakamoto A, Murata N (2002) The role of glycinebetaine in the protection of plants from stress: clues from transgenic plants. Plant Cell and Environ 25:163-171

27. Ashraf M, Foolad MR (2007) Roles of glycine betaine and proline in improving plant abiotic stress resistance. Environ Exp Bot 59:206-216

28. Sakamoto A, Alia MN (1998) Metabolic engineering of rice leading to biosynthesis of glycinebetaine and tolerance to salt and cold. Plant Mol Biol 38:1011-1019

29. Huang J, Hirji R, Adam L, Rozwadowski KL, Hammerlindl JK, Keller WA, Selvaraj G (2000) Genetic engineering of glycine-betaine production towards enhancing stress tolerance in plants: metabolic limitations. Plant Physiol 122:747-756

30. Quan R, Shang M, Zhang H, Zhao Y, Zhang J (2004) Improved chilling tolerance by transformation with betA gene for the enhancement of glycinebetaine synthesis in maize. Plant Sci 166:141-149

31. Shirasawa K, Takabe T, Takabe T, Kishitani S (2006) Accumulation of glycinebetaine in rice plants that overexpress choline monooxygenase from spinach and evaluation of their tolerance to abiotic stress. Ann Bot 98:565-571

32. Clendennen SK, May DG (1997) Differential genes expression ripening banana fruit. Plant Physiol 115:463-469

33. Tamayo CJA (2002) Study of the poliphenol oxidase system of the fruit of the chicozapote (Achras sapota), PhD thesis. Instituto Tecnológico de Mérida, Mérida, Yucatán. México, p 81

34. Arzápalo MAM (2002) Mono and diphenolase activity from crude extracts of chicozapote (Achras sapota, Manilkara achras Mill.) Master's thesis in Biotechnology. Instituto Tecnológico de Mérida, Merida Yucatan, p 76 p

35. Singleton VL, Rossi JA (1965) Colorimetry of total phenolics with phosphomolybdic-phosphotungstic acid reagents. Am J Enol Vitic 16:144-158

36. Bradford MM (1976) A rapid and sensitive method for the quantitation of microgram protein utilizing the principle of protein dye binding. Anal Biochem 72:248-254

37. Wellburn AR (1994) The spectral determination of chlorophyll a and b, as well as total wholefood, using various solvents with spectrophotometers of different resolution. J Plant Physiol 144:307-313

38. McCollum TG, McDonald RE (1991) Electrolyte leakage, respiration, and ethylene production as index of chilling injury in grapefruit. HortSc 26(9):1191-1192

39. Liu X, Shiomi S, Nakatsuka A, Kubo Y, Nakamura R, Inaba A (1999) Characterization of ethylene biosynthesis associated with in banana fruit ripening. Plant Physiol. Vol 121. 1257-1265

40. Chillet M, Lapeyre Bebellaire $L$ (2002) Variability in the production of ethylene in banana from wound the French West Indies. Sci-fi Hort 96:127-137

41. Prohens J, Miró R, Rodriguez-Burruezo A, Chiva S, Verdú G, Nuez F (2004) Temperature, electrolyte, ascorbic acid content and sunscald in two cultivars of cucumber, Solanum muricatum. J Hort Sci Biotechnol 79(3):375-379

42. Maxwell K, Johnson GN (2000) Chlorophyll fluorescence -a practical guide. J Exp Bot 51:659-668 
43. Morrelli KL, Hess-Pierce BM, Kader AA (2003). Genotypic variation in chilling sensitivity of mature-green bananas and plantains. Hort Technology 13(2):328-332.

44. Park EJ, Jeknic Z, Sakamoto A, DeNoma J, Yuwansiri R, Murata N, Chen THH (2004) Genetic engineering of glycinebetaine synthesis in tomato protects seeds, plants, and flowers from chilling damage. Plant J 40:474-487

45. Coseteng M, Lee CY (1987) Changes in apple polyphenol-oxidase and polyphenol concentration in relation to degree of browning. J Food Sci 52:985-989

46. Nguyen TBT, Ketsa S, Van-Doorn WG (2004) Effect of modified atmosphere packaging on chilling-induced peel browning in banana. Postharvest Biol Technol 31:313-317

47. Brady CJ, O'Connell PBH (1976) On the significance of increased protein synthesis in ripening banana fruits. Aust J Plant Physiol 3:301-310

48. Hubbard NL, Mason Pharr D, Huber SC (1990) Role of sucrose phosphate synthase in sucrose biosynthesis in ripening bananas and its relationship to the respiratory climacteric. Plant Physiol 94:201-208

49. Blackbourn HD, Jeger MJ, John P, Thompson AK (1990) Inhibition of degreening in the peel of bananas ripened at tropical temperatures. Ann App Biol 117:175-186

50. Lyons JM, Breidenbach RW (1990) Relation of chilling stress to respiration. Ed. C.Y. Wang. Chilling injury of horticultural crops. CRC Press, In, pp 223-233

51. Field RJ (1990) Influence of chilling stress on ethylene production. Ed. C.Y. Wang. Chilling injury of horticultural crops. CRC Press. Mouse palate, In, pp 235-253

52. Leshem $Y Y$, Kaddish D (1992) Membrane related effects of chilling stress on ethylene production in green peppers stored at $4^{\circ} \mathrm{C}$ as compared to $17^{\circ} \mathrm{C}$ (shelf temperature). Res. Report. BARD Foundation, u.S.-Israel, pp 1-23

53. Lyons JM (1973) Chilling injury in plants. Annu Rev Plant Physiol Plant Mol Biol 24:445-466

54. Jiang Y, Joyce DC, Jiang W, Lu W (2004) Effect of chilling injury on binding bye banana fruit ethylene. Plant Growth Regul 43:109-115

55. Park EJ, Jeknic Z, Chen TH (2006) Exogenous application of glycinebetaine increases chilling tolerance in tomato plants. Plant Cell Physiol 47(6):706-714

56. Hu L, Hu T, Zhang X, Pang H, Fu J (2012) Exogenous glycine betaine ameliorates the adverse effect of salt stress on perennial ryegrass. J Amer Soc Hort Sci 137:38-46

57. DeEll JR, van Kooten O, Prange RK, Murr DP (1999) Applications of chlorophyll fluorescence techniques in postharvest physiology. Hortic Rev 23:69-107

58. Holden M (1961) The breakdown of chlorophyll by chlorophyllase. Biochem J 78:359-364

59. Tucker GA (1993) Introduction. In: Seymour GB, Taylor JE, Tucker GA (eds) Biochemistry of fruit ripening. Chapman \& Hall, London, pp 1-51

60. Sanxter SS, Yamamoto HY, Fisher DG, Chan HT (1992) Development and decline of chloroplasts in exocarp of Carica papaya. Can J Bot 70:364-373

61. Marangoni AG, Palma T, Stanley DW (1996) Membrane effects in postharvest physiology. Postharvest Biol Technol 7:193-217

62. Lurie S, Ronen R, Meier S (1994). Determining chilling injury induction in green peppers using nondestructive pulse amplitude modulated (PAM) fluorometry. J Am Soc Hortic Sci 119:59-62

63. Van Kooten O, Mensink MGJ, Otma EC (1992) Chilling damage of dark stored cucumbers (Cucumis sativus L.) affects the maximum quantum yield of photosystem 2. In: MURATA N (ed) Progress in photosynthesis research. Kluwer, The Netherlands, pp 161-164

64. Quan R, Shang M, Zhang H, Zhao Y, Zhang J (2004) Engineering of enhanced glycine betaine synthesis improves drought tolerance in maize. Plant Biotechnol J 2:477-486

65. Fan $W$, Zhang $M$, Zhang $H$, Zhang $P$ (2012) Improved tolerance to various abiotic stresses in transgenic sweet potato (Ipomoea batatas) expressing plant signaling. Behav 6(11):1746-1751

\section{Submit your manuscript to a SpringerOpen ${ }^{\odot}$ journal and benefit from:}

- Convenient online submission

- Rigorous peer review

- Immediate publication on acceptance

- Open access: articles freely available online

- High visibility within the field

- Retaining the copyright to your article

Submit your next manuscript at $>$ springeropen.com 